\title{
The Analysis of industrial cooperation models in the context of forming digital economy ${ }^{a}$
}

\author{
Aleksandr Babkin $^{1 *}$, Vladimir Plotnikov ${ }^{2}$, and Yulia Vertakova $^{3}$ \\ ${ }^{1}$ Peter the Great St. Petersburg Polytechnic University, 195251, Politechnicheskaya st., 29, Russian \\ Federation \\ ${ }^{2}$ Southwest State University, Kursk, 50 let Oktyabrya, 94, Russian Federation \\ ${ }^{3}$ Saint Petersburg State University of Economics, 191023, 21, Sadovaya street, 21 Russian Federation
}

\begin{abstract}
Approaches which enable improving the efficiency of industrial enterprises functioning in the context of forming digital economy are discussed in the article. In contrast to the traditional analysis of this problem on macro- (national economy in general, creating a favorable institutional environment for industrial development and digitalizing of economy) or micro- (development of recommendations for implementing digital technologies in manufacturing and management subsystems of industrial enterprises) levels, the authors consider a meso-level. Studies undertaken have made it possible to come to a conclusion that current digitalization of both enterprises and industry in total determines the changes of industrial cooperation models. It has been indicated that significant opportunities for effective development of industry are connected with forming integrative groups of cooperation-interactive enterprises. Such models of interaction as outsourcing, cluster and strategic alliance have been considered and their pros and cons have been revealed. Recommendations on designing cooperation interaction between industrial enterprises have been formulated. The design is oriented on improving the effectiveness of using resources and reducing risks.
\end{abstract}

\section{Introduction}

Technological revolution of the contemporary world is closely related to digitalization of industry and its reorganization in accordance with new management principles $[1,2]$. It is clearly seen that both developing and developed countries are eager to win technological leadership. The potential for that is formed not only at the micro- and macro- but also at the meso-level. At that, the indicated levels of industry management have their specific character and differ in the degree of development of competitive ability (technological leadership)

\footnotetext{
${ }^{a}$ This paper is an output of the science project of the government task of Ministry of education and science of the Russian Federation № 26.3546.2017/PCH “Development fundamentals of analysis and prediction of structural and dynamic parameters of the regional economy are based on the integration of the Russian and world experience of management of territorial development and modern scientific doctrines"

*Corresponding author: $\underline{\text { al-vas@mail.ru }}$
} 
forming instrumentarium.

At the micro-level we are talking about new technologies: their implementing can increase productivity of labor, quality of production, reduce costs; improve ecological characteristics of production activity of enterprises etc. The given range of problems is the focus of attention of a considerable number of foreign [3-5] and Russian specialists [6, 7] who investigate both merely technological and also organizational issues. The latter ones to a large extent are connected with the development of automated control systems for production processes and also with implementing digital management systems.

As a rule, issues of state regulation of innovative technological development of national economies are considered at the macro-level in the considered context. This theme is very popular not only in scientific studies [8] but it is also institutionally confirmed in the system of state administration documents. For instance, the program of "Digital Economy of the Russian Federation" is approved in Russia by the government executive order of July 28, 2017, No. 1632-r [9]. This document determines goals, objectives, directions and terms of realization of basic measures of state policy on creating necessary conditions for developing digital economy in the country. Variation of the suggested economic model from the existing one lies in the fact that data in digital form is considered to be the key factor of production.

The meso-level of forming competitive ability of industry in the new technological era and also forming technological leadership is less explored and investigated. What is it related to? Contemporary technologies are constantly complicating. As the result, division of labor is becoming more and more evident, as well as such phenomena as production specialization and cooperation of production units. Besides fundamental difference of new conditions connected with rapid development of digital technologies lies in the fact that the indicated cooperation becomes flexible. There appears an opportunity for reorganizing cooperation chains in real time scale. It enables improving industry efficiency. Technological opportunities appear that enable forming consortiums of "smart factories", dynamic optimization of production according to different criteria.

Issues of developing organization of interaction processes in industry at the meso-level are traditionally explored within the framework of development dealing with business networks [10-12]. But elaboration of contemporary digital technologies leads to the necessity of further investigation of the indicated subject area that determines its applicability.

\section{Research aim}

The aim of the undertaken research is analysis of organizational forms and industrial cooperation models in the context of forming digital economy.

\section{Organizational forms of industrial cooperation of enterprises}

Cooperation is an objective phenomenon. In modern industry, especially in high-tech one, implementation of engineering and manufacturing operations within the framework of one economical unit is not effective. It is related to such factors as scale effect, minimum effective scale of production, localization of resources, institutional environment, profits of localization and others. The study undertaken by the authors indicated that the most commonly available forms of cooperation are outsourcing, cluster and strategic alliance.

Outsourcing. The essence of outsourcing is in passing a variety of functions from a customer company to an executive (outsourcing agent) in order to concentrate the first function on key competencies and make secondary (outsourced) processes cheaper. Finally a situation is possible when the head company of such an outsourcing system is transformed 
into a management center and all production processes are passed to specialized performers. This model got widespread in electronic and telecommunication industry [13].

An illustrative example is production of iPhone. A mass consumer is sure (to a large extent influenced by advertisement) that it is a product of American industry. But it's not so. The Apple company office and development center are located in Cupertino, California. All manufacturing processes are being outsourced and they are implemented mostly in East Asia. At that, a model of double-level cooperation is being used. Production of component parts is implemented in Samsung enterprises (processors), LG enterprises (displays), etc. The final assembling of iPhone components is made at the Foxconn factory which is located in Shenzhen (China, Guangdong province).

In the context of globalization and distribution of informational and communicational technologies production outsourcing is becoming a global phenomenon. Elements of production process with high labor intensity and ecologically destructive companies of developing countries are being taken out abroad, in the countries with a low level of living and poor state regulation.

Clusters. The theory of cluster development was suggested by M. Porter [14]. According to him, clusters promote increasing competitive ability of enterprises thanks to the agglomerative effect which, in its turn, is governed by territorial concentration of industrial productions and organizations related to them (educational, scientific, engineering, logistic, etc.)

The activity in forming clusters of our epoch (beginning with 1970es) is specifically connected with processes of disintegration of vertically integrated companies and structures [15]. The basic reason for the processes was cardinal upgrade of complexity of production first of all in machine engineering. The number and assortment of semi-finished products and components, used in final assembly of products, have increased manifold. In these conditions concentration of all production sites under the roof of one vertically integrated structure is no longer a realistic choice. The alternative variant is cooperation of independent producers on a mutually beneficial basis that is a cluster. Being an originator of the cluster approach $\mathrm{M}$. Porter defines cluster as a "group of geographically neighboring interconnected companies and organizations related to their activity which function in a particular sphere and are characterized by the commonness of their activity and are mutually supportive" [14]. The given definition to the full extent reflects the essence of a cluster as an economic and geographic unit. The focus is that a cluster, as a rule, is not something isolated but a part of an integrated system. Here again, it is necessary to suggest that there is certain interconnection and interdependence between clusters within the limits of the system and that determines successful functioning of clusters.

Besides enabling cost saving and competitive advantage related to that, clusters also represent a powerful tool of innovative development. They have got widespread and their dynamics can be monitored by national regulators that support the business community in forming and developing clusters. Such projects as Cluster Mapping (USA, http://clustermapping.us), Cluster Observatory (EU, http://www.clusterobservatory.eu), Russian Cluster Observatory (Russia, http://cluster.hse.ru/clusters) and many other ones are focused on that. In particular, active creation of innovative territorial clusters in Russia is subject to the commission of the Chairman of the Government of the Russian Federation DM-P8-5060 of 28.08.2012. At the moment more than 90 innovative territorial clusters are created in Russia [16].

Organization of clusters is one of the forms of innovative development support including assistance in those branches and types of activity related to computerization and digital technologies.

Strategic alliances. A strategic alliance is association of companies for combined achievement of long-term goals and solving the problems of strategic development. It 
suggests close cooperation and may be completed with consolidation of companies, creating a joint enterprise or exchanging assets. As a rule, the motive for creating alliances in industry is obtaining new competencies by participants and a synergetic effect of their consolidating [12].

Companies in the alliance should complement each other and intensify competitive advantages. In this case there is a significant number of limitations for their creation both of organizational and legal nature and also of technological nature. It is a common practice that former competitors unite in an alliance. This leads to increased attention to procedures of their creation from antimonopoly services and other regulating authorities of the state and supernational level.

Each of the considered forms of cooperation of enterprises differs in its peculiarities. Comparison of outsourcing, cluster and strategic alliance characteristics is made in Table 1 on the basis of analysis [5-7]. While selecting a specific model for cooperation of enterprises it is necessary to take into account the specific nature of the considered organizational forms. In particular, for concrete projects hybrid forms of interaction organization can be constructed which take into account limitations and specific nature of these projects.

While selecting a form for cooperation of enterprises in contemporary conditions it is necessary to take into account the dependence of its model on the utilized system of informational exchange between them. Architecture and its constructions, composition, compatibility of separate elements and functional capacities are also important factors influencing the selection of the model of enterprise cooperation.

Table 1. Comparative analysis of outsourcing, cluster and strategic alliance.

\begin{tabular}{|l|l|l|l|}
\hline Attribute & Outsourcing & Cluster & Strategic alliance \\
\hline Subjects of cooperation & $\begin{array}{l}\text { Technologically } \\
\text { related enterprises }\end{array}$ & $\begin{array}{l}\text { Enterprises localized } \\
\text { in one territory }\end{array}$ & $\begin{array}{l}\text { Enterprises- } \\
\text { competitors }\end{array}$ \\
\hline Industrial coverage & One branch & Different branches & One branch \\
\hline $\begin{array}{l}\text { Driver of efficiency of } \\
\text { cooperative activity }\end{array}$ & $\begin{array}{l}\text { Involvement of } \\
\text { resources and } \\
\text { competencies of a } \\
\text { business partner, } \\
\text { distribution of risks }\end{array}$ & $\begin{array}{l}\text { Territorial proximity } \\
\text { (reduction of logistic } \\
\text { costs) and cooperative } \\
\text { utilization of resources }\end{array}$ & $\begin{array}{l}\text { Synergy of } \\
\text { combining } \\
\text { resources and } \\
\text { competencies }\end{array}$ \\
\hline Type of cooperation & Principal - agent & $\begin{array}{l}\text { Different forms of } \\
\text { cooperation }\end{array}$ & Partnership \\
\hline Formal fixation of relations & Present & Absent & Present \\
\hline $\begin{array}{l}\text { Availability of a coordinating } \\
\text { center }\end{array}$ & Present & Absent & Present \\
\hline Scheme of creation & $\begin{array}{l}\text { Goal-oriented } \\
\text { organization }\end{array}$ & $\begin{array}{l}\text { Self-organization, } \\
\text { including that on the } \\
\text { basis of external } \\
\text { stimulation }\end{array}$ & $\begin{array}{l}\text { Goal-oriented } \\
\text { organization }\end{array}$ \\
\hline
\end{tabular}




\section{Comparative analysis of models of production cooperation of enterprises}

The studies undertaken [5-7] have indicated that in most cases for the analysis of production cooperation of enterprises such types and forms of activity are distinguished as outsourcing, cluster formations and strategic alliances.

Let us analyze outsourcing, clusters and strategic alliances from the perspective of their utilization efficiency in modern industry and taking the "digital revolution" into account. Development of informational and communicational technologies, blockchain technologies and processes of industrial digitalization related to them determine extensive application of these forms of cooperation and models of cooperation of enterprises. Such models in industry include a set of business characteristics defining the behavior of an economic entity on the market, the structure of property rights, mechanisms of management and control, forms of participating in the activity of every collaborative agent, etc.

Let us consider the basic advantages and disadvantages common to each model of cooperation.

Outsourcing. Relations that are defined by the model of "principal - agent" in economical theory take place in outsourcing. An agent (outsourcer), using its own resources, organizes performing of functions which can't be performed by a principal (customer). The reason for that is either lack of relevant competencies or a strategic decision to concentrate resources on those functions and processes that are considered to be the key ones.

Connections within the framework of this model can be very stable. This is shown, in particular, by the experience of world electronic industry where OEM-production has got widespread and, in fact, it has become an important factor of providing competitiveness. Specialized outsourcers that manufacture production for different customers under contracts, thanks to scale and training effects enable providing a high level of quality and low cost price. And their significant work and competency experience allows for providing flexibility of production program and low risks for a customer. Besides, trans-border outsourcing serves as a tool for legal optimization of tax burden.

Stability of cooperation guarantees that in the case of breach of relations it will be difficult for both the parties to find a new business partner. It is determined by the observed high level of specialization of enterprises which take part in outsourcing and are related to these competitive advantages. Within the framework of an outsourcing model, two connected elements of a production chain are formed and actively function. Guarantees of this functioning are of formal (contract obligations) and informal (mutual interest of parties in cooperation) nature.

Apart from merits outsourcing has also demerits. Interdependence of partners may result in a situation where one of them, who has a more significant market power, will take advantage of its position. In consequence of that the other partner will either incur losses or lose its key competencies and withdraw from the market. In the tumultuous economic environment (lack of stability in modern world grows) and in the presence of low credibility it is very likely that participants of potential outsourcing relations will be more concerned in the issues of their survival rather than in obtaining a mutual effect within the context of outsourcing. This risk needs special regulation and cooperative overcoming (with the participation of partners).

Clusters. An important distinguishing feature if a cluster is spontaneous character of its generation and functioning. Even in those cases when a major company or a state is demonstrating a cluster initiative it is not quite evident that this initiative will be successful. In any case, a cluster is formed and developed only in the presence of relevant stimuli. As a result, cooperation of enterprises inside a cluster is notable for its flexibility. Besides, thanks to importance of a cluster for regional development, government institutions and non-profit 
organizations are actively drawn into it (for example, universities). On the basis of the studies [15] advantages and disadvantages of clusters are represented in Table 2.

Table 2. Comparative analysis of advantages and disadvantages of clusters in industry.

\begin{tabular}{|l|l|}
\hline Advantages & Disadvantages \\
\hline $\begin{array}{l}\text { Interbranch nature and, as a rule, complexity of } \\
\text { relations, stability }\end{array}$ & $\begin{array}{l}\text { Spontaneous nature of forming that } \\
\text { generates risks of cluster initiatives }\end{array}$ \\
\hline $\begin{array}{l}\text { Favorable environment for diffusion of innovations and } \\
\text { technologies transfer }\end{array}$ & Absence of formal regulation \\
\hline $\begin{array}{l}\text { Involvement of non-profit organizations and } \\
\text { government institutions }\end{array}$ & $\begin{array}{l}\text { Absence of centralized management or at } \\
\text { least coordination of combined actions. }\end{array}$ \\
\hline $\begin{array}{l}\text { Network structure enables successful implementation } \\
\text { of digital economy technologies and practicability of } \\
\text { forming digital platforms }\end{array}$ & Risks of informational security \\
\hline
\end{tabular}

An important advantage of a cluster is that many elements of production and selling chains function in it and, what's interesting is that they often function in neighboring branches. At that, thanks to continuous cooperation, active diffusion of innovations and technologies transfer take place between enterprises of the cluster and it allows for increasing the efficiency of enterprises. At the same time one should keep in mind that it's impossible to create a cluster, it is possible only to enable its generation and development. The efforts of one enterprise or their consortium may be not enough for creating such conditions, support of the state may be also necessary. This peculiarity of clusters produces institutional limitations for their application.

Strategic alliances. The essence of a strategic alliance is partnership of independent enterprises-competitors in order to increase the competitive ability of each of them. At that, in contrast to a classical cartel, competitiveness for a customer is preserved. In an alliance competitors optimize the structure of their resources and also get the opportunity of implementing (using the partner's resources) those projects which it would be impossible to implement acting alone.

The important advantage of cooperation within the framework of a strategic alliance is the fact that it allows for increasing the efficiency of utilization of resources of the competitors while keeping competition between them, including that on the basis of forming integrated intellectual digital platforms. Both competitors (thanks to combining resources) and also consumers (competition for them is preserved) win, that is society on the whole. Nevertheless strategic alliances, as a rule, are under the spotlight of antimonopoly authorities and that generates risks for their successful functioning.

These risks are connected with the fact that there are no strict criteria which are regularized and would allow to clearly distinguishing a strategic alliance and a cartel. As a result the risk is very high that the alliance will be characterized by supervisory authorities as a cartel and its creation and functioning will be prohibited. Besides, both the government and competitors that are not in the alliance can take the initiative to introduce the ban. Therefore a strategic alliance can successfully function only if it is supported by the state. 


\section{Conclusions}

Thus, according to the results of the analysis we can make the conclusion that in the context of forming digital economy the dependence of industry efficiency on organization of their cooperation interaction increases. This dependence is especially relevant to high-tech and innovative industries which are distinguished by high capital and knowledge costs. In this regard, their implementation by separate companies (even having significant resources and competencies) becomes impossible.

The studies undertaken by the authors $[6,7,12]$ allowed concluding that digitalization of enterprises and industry on the whole that takes place at the present time determines changes of models of industrial cooperation. The most promising forms of cooperation of enterprises are outsourcing, clusters and strategic alliances. Each of these models has certain advantages and disadvantages therefore for organization of cooperation of enterprises in specific projects it is necessary to thoroughly develop and fix in a contract the interaction model every time in order to take the advantage for participants and manage risks. State regulation is meant to play an important part in solving these problems.

Besides, when selecting the model for cooperation interaction it is recommended to use hybrid organizational forms which combine the elements of outsourcing, clusters and strategic alliances. In the interaction design it is also important to take into account external and internal informational infrastructure of cooperating enterprises, its composition, functional capabilities and architecture. This will enable cooperating not only at the management but also at the technological level which will promote its efficiency and productivity.

\section{References}

1. B. M. Allen, Journal of Library Administration, 48(1) (2008)

2. S. J. Andriole, The 2nd Digital Revolution (IGI Global 2005)

3. P. Tambe, L.M. Hitt, Management Science 60(2) (2014)

4. J. A. Mañez, M. E. Rochina-Barrachina, A. Sanchis, J. A. Sanchis, Empirical Economics, 44(3) (2013)

5. C. Ménard, Journal of Institutional and Theoretical Economics, 160 (2004)

6. A. Y. Karlick, V. D. Morozova, News of the Saint Petersburg State University of Economics, 2 (2001)

7. A.V. Babkin, V. A. Plotnikov, S. V. Muraveva, Proceedings of the 25th International Business Information Management Association Conference - Innovation Vision 2020: From Regional Development Sustainability to Global Economic Growth, IBIMA. (2015)

8. V. P. Vorobjev, N. N. Tikhomirov, News of the Saint Petersburg State University of Economics, 3 (99) (2016)

9. On confirming the program "Digital economy of the Russian Federation". RF Government Executive Order, 28.07.2017, No. 1632-r. [online], Available at: http://base.consultant.ru (2017)

10. A. Grandori, G. Soda, Organization Science, 16(2) (1995)

11. S. V. Starikov, Organizing import-substituting production on the basis of network cooperation of industrial enterprises: Thesis for a Candidate Degree of Economic Sciences. (Kursk 2017)

12. V. Plotnikov, Y. Vertakova, Procedia Economics and Finance, 24 (2015) 
13. G. Kleyner, A. Babkin, Lecture Notes in Computer Science (including subseries Lecture Notes in Artificial Intelligence and Lecture Notes in Bioinformatics). 9247. (2015)

14. M. E. Porter, Harvard business review. 76(6) (1998)

15. A. V. Babkin, A. O. Novikov, Scientific and technological journal of the Saint Petersburg State University of Economics. Economic sciences. 1 (235) (2016)

16. Russian Cluster Observatory [online] Available at: http://cluster.hse.ru/clusters (2018) 